\title{
Extended-Spectrum $\beta$-lactamase-Producing Enterobacteriaceae Shedding in Farm Horses Versus Hospitalized Horses: Prevalence and Risk Factors
}

\author{
Anat Shnaiderman-Torban ${ }^{1}$, Shiri Navon-Venezia ${ }^{2,3,+}{ }^{\dagger}$, Ziv Dor $^{2}$, Yossi Paitan ${ }^{4,5}$, Haia Arielly ${ }^{5}$, \\ Wiessam Abu Ahmad ${ }^{6}$, Gal Kelmer ${ }^{1}$, Marcus Fulde ${ }^{7}$ and Amir Steinman ${ }^{1, *, \dagger}$ \\ 1 Koret School of Veterinary Medicine (KSVM), The Robert H. Smith Faculty of Agriculture, \\ Food and Environment, The Hebrew University of Jerusalem, Rehovot 7610001, Israel; \\ ashnaiderman@gmail.com (A.S.-T.); gal.kelmer@mail.huji.ac.il (G.K.) \\ 2 Department of Molecular Biology, Faculty of Natural Sciences, Ariel University, Ariel 40700, Israel; \\ shirinv@ariel.ac.il (S.N.-V.); zivddor@gmail.com (Z.D.) \\ 3 The Miriam and Sheldon Adelson School of Medicine, Ariel University, Ariel 40700, Israel \\ 4 Department of Clinical Microbiology and Immunology, Sackler Faculty of Medicine, Tel Aviv University, \\ Tel Aviv 6997801, Israel; yossi.paitan@clalit.org.il \\ 5 Clinical Microbiology Lab, Meir Medical Center, Kfar Saba 4428164, Israel; Ariellyhaya@clalit.org.il \\ 6 Braun School of Public Health and Community Medicine, Hebrew University, Jerusalem 9112102, Israel; \\ wiessam@gmail.com \\ 7 Institute of Microbiology and Epizootics, Department of Veterinary Medicine at the Freie Universität Berlin, \\ Berlin 14163 Germany; Marcus.Fulde@fu-berlin.de \\ * Correspondence: amirst@savion.huji.ac.il \\ + These authors had equal contribution.
}

Received: 15 January 2020; Accepted: 7 February 2020; Published: 11 February 2020

Simple Summary: This prospective study investigated the prevalence, molecular characteristics and risk factors of extended-spectrum $\beta$-lactamase (ESBL)-producing Enterobacteriaceae (ESBL-E) shedding in three equine cohorts: (i) farm horses (13 farms, $\mathrm{n}=192$ ); (ii) on admission to a hospital ( $\mathrm{n}=168$ ) and; (iii) horses hospitalized for $\geq 72 \mathrm{~h}$ re-sampled from cohort (ii) $(\mathrm{n}=86)$. Bacteria were isolated from rectal swabs, identified, antibiotic susceptibility patterns were determined, and medical records and owners' questionnaires were analyzed for risk factor analysis. ESBL shedding rates significantly increased during hospitalization $(77.9 \%, \mathrm{n}=67 / 86)$, compared to farms $(20.8 \%, \mathrm{n}=$ $40 / 192)$, and horses on admission $(19.6 \%, n=33 / 168)$. High bacterial species diversity was identified, mainly in cohorts (ii) and (iii), with high resistance rates to commonly used antimicrobials. Risk factors for shedding in farms included horses' breed (Arabian), sex (stallion), and antibiotic treatment. Older age was identified as a protective factor. We demonstrated a reservoir for antibiotic-resistant bacteria in an equine hospital and farms, with a significant ESBL-E acquisition. In light of our findings, in order to control ESBL spread, we recommend conducting active ESBL surveillance programs alongside antibiotic stewardship programs in equine facilities.

Abstract: We aimed to investigate the prevalence, molecular characteristics and risk factors of extended-spectrum $\beta$-lactamase (ESBL)-producing Enterobacteriaceae (ESBL-E) shedding in horses. A prospective study included three cohorts: (i) farm horses (13 farms, $\mathrm{n}=192)$; (ii) on hospital admission ( $\mathrm{n}=168$ ) and; (iii) horses hospitalized for $\geq 72 \mathrm{~h}$ re-sampled from cohort (ii) $(\mathrm{n}=86)$. Enriched rectal swabs were plated, ESBL-production was confirmed (Clinical and Laboratory Standards Institute (CLSI)) and genes were identified (polymerase chain reaction (PCR)). Identification and antibiotic susceptibility were determined (Vitek-2). Medical records and owners' questionnaires were analyzed. Shedding rates increased from $19.6 \%(n=33 / 168)$ on admission to $77.9 \%(n=67 / 86)$ during hospitalization $(p<0.0001$, odds ratio $(\mathrm{OR})=12.12)$. Shedding rate in farms was $20.8 \%$ ( $n=40 / 192)$, significantly lower compared to hospitalized horses $(p<0.0001)$. The main ESBL-E species 
( $\mathrm{n}=192$ isolates) were E. coli $(59.9 \%, 115 / 192)$, Enterobacter sp. $(17.7 \%, 34 / 192)$ and Klebsiella pneumoniae $(13.0 \%, 25 / 192)$. The main gene group was CTX-M-1 (56.8\%). A significant increase in resistance rates to chloramphenicol, enrofloxacin, gentamicin, nitrofurantoin, and trimethoprim-sulpha was identified during hospitalization. Risk factors for shedding in farms included breed (Arabian, OR = 3.9), sex (stallion, $\mathrm{OR}=3.4)$, and antibiotic treatment $(\mathrm{OR}=9.8)$. Older age was identified as a protective factor $(\mathrm{OR}=0.88)$. We demonstrated an ESBL-E reservoir in equine cohorts, with a significant ESBL-E acquisition, which increases the necessity to implement active surveillance and antibiotic stewardship programs.

Keywords: equine; ESBL-E; antibiotic resistance; shedding; risk factors; farm; ESBL-E acquisition

\section{Introduction}

Extended-spectrum beta-lactamase (ESBL)-producing Enterobacteriaceae (ESBL-E) poses a clinical challenge to both human and veterinary clinicians. ESBLs confer resistance to penicillins, cephalosporins, and aztreonam and are often accompanied by fluoroquinolone resistance, which even further narrows antibiotic treatment options [1]. Moreover, many ESBL genes are encoded on large plasmids, which enables lateral transfer between different bacterial species, within the same host and between different hosts [2]. In human medicine, ESBL production is associated with increased morbidity, higher overall and infection-related mortality, increased hospital length of stay, delay of targeted appropriate treatment, and higher costs [3,4]. Risk factors for colonization and infection in humans include severe illness with prolonged hospital stays, the presence of invasive medical devices for a prolonged duration and antibiotic use [2].

Within the last decade, a growing burden of ESBL-E in companion animals is being observed, both as gut colonizing bacteria and as infecting pathogens, causing wounds, respiratory, urogenital, gastro-intestinal, umbilical infections, and bacteremia [5-8]. Horses were described as carriers, as well as infected by ESBL-E, in equine clinics and in farm settings [9,10]. Prevalence of ESBL-producing E. coli carriage in horses varies between $4-44 \%$ in different European countries [11-13], with a lower carriage prevalence in equine riding centers in comparison with equine clinics [10]. In equine community settings, being stabled in the same yard with a recently hospitalized horse was identified as a risk factor for ESBL-producing E. coli carriage [14]. Risk factor analysis in the level of the farm revealed that the odds of being an ESBL/AmpC-producing E. coli premises were higher among riding schools than breeding premises, if premises housed a horse that had been medically treated with antibiotics within the last three months, and also in premises where the staff consisted of more than five persons [13]. However, risk factors for shedding of different ESBL-E species within horses were not yet reported.

We aimed to investigate and compare ESBL-E shedding in different equine cohorts, including farm horses, horses on admission to an equine hospital and during hospitalization, as well as to determine risk factors for shedding. We hypothesized that shedding rates increase during hospitalization, that previous antibiotic treatment is a risk factor for shedding and that shedding on admission and during hospitalization is associated with clinical signs, prolonged hospitalization, and severe outcome.

\section{Materials and Methods}

\subsection{Equine Study Cohorts, Study Design, and Sampling Methods}

This prospective study was performed on 13 farms throughout Israel and in the Koret School of Veterinary Medicine-Veterinary Teaching Hospital (KSVM-VTH). The study was approved by the Internal Research Review Committee of the KSVM-VTH (Reference numbers: KSVM-VTH/15_2015, KSVM-VTH/23_2015). Rectal swabs were collected from the horses with owner consent. On admission, sampling was performed prior to any medical treatment in the hospital. When horses survived and 
were not discharged, a second sample was taken $72 \mathrm{~h}$ post-admission. Farm horses were located in different regions of Israel to roughly represent the population.

\subsection{Demographic and Medical Data}

For farm horses (cohort (i)), owners' questionnaires were reviewed for data regarding individual horses, including the originating farm, signalment (age, sex, and breed), duration of the horse's accommodation in the farm, hospitalization and antibiotic treatments within the previous year.

For hospitalized horses (cohort (ii)), medical records were reviewed for the following information: signalment (age, sex, and breed), geographic origin, previous admission to the hospital within the previous year (yes/no), clinical signs, duration of illness before admission, antibiotic therapy before and during hospitalization, surgical procedures, other medications, hospitalization length, short-term outcome, and admission charge.

\subsection{ESBL-E Isolation and Species Identification}

Rectal specimens [14] were collected using bacteriological swabs (Meus s.r.l., Piove di Sacco, Italy) and were inoculated directly into a Luria Bertani infusion enrichment broth (Hy-Labs, Rehovot, Israel) to increase the sensitivity of ESBL-E detection [15]. After incubation at $37^{\circ} \mathrm{C}(18-24 \mathrm{~h})$, enriched samples were plated onto Chromagar ESBL plates (Hy-Labs, Rehovot, Israel), at $37^{\circ} \mathrm{C}$ for $24 \mathrm{~h}$. Colonies that appeared after overnight incubation at $37^{\circ} \mathrm{C}$ were recorded, and one colony of each distinct color was re-streaked onto a fresh Chromagar ESBL plate to obtain a pure culture. Pure isolates were stored at $-80{ }^{\circ} \mathrm{C}$ for further analysis.

Isolates were subjected to Vitek-MS (BioMérieux, Inc., Marcy-l'Etoile, France) for species identification or to Vitek-2 (BioMérieux, Inc., Marcy-l'Etoile, France) for species identification and/or antibiotic susceptibility testing (AST-N270 Vitek 2 card). Chloramphenicol, enrofloxacin, and imipenem were analyzed using disc diffusion assay (Oxoid, Basingstoke, UK). ESBL-production was confirmed by combination disk diffusion using cefotaxime and ceftazidime discs (Oxoid, Basingstoke, UK), as well as cefotaxime and ceftazidime with clavulanic acid (Sensi-Discs BD, Breda, The Netherlands). Results were interpreted according to the Clinical and Laboratory Standards Institute (CLSI) guidelines [16]. Multidrug-resistant (MDR) bacteria were defined as such due to their in vitro resistance to three or more classes of antimicrobial agents [17].

\subsection{Molecular Characterization of ESBL-E}

Isolates were examined for the presence of the blaCTX-M group using a multiplex polymerase chain reaction (PCR) from ESBL-E DNA lysates, as previously described [18]. Isolates that were found to be blaCTX-M PCR negative were further examined for the presence of blaOXA-1, blaOXA2, blaOXA10 [19], blaTEM, and blaSHV groups [20]. ESBL-producing E. coli isolates were subjected to PCR for the detection of $m d h$ and $g y r B$ genes in order to determine the presence of the worldwide pandemic E. coli ST131 lineage [21].

\subsection{Sample Size and Statistical Analysis}

The minimal sample size (number of animals sampled) for farm horses was calculated using WinPepi, based on an estimated shedding rate of $25 \%$ for ESBL-E in equine community livery premises [22] and on the fact that Israel is endemic for ESBL-E [23], with a confidence level of $95 \%$ and an acceptable difference of $7 \%$, resulting in $n=147$.

The minimal sample size for horses on admission to hospital was based on the expected difference between ESBL-E shedding and non-shedding horses and the percentage of admitted horses that were treated with antibiotics before admission since antibiotic treatment was assumed to be a risk factor for shedding [12]. Since there is no previous study revealing percentages of antibiotic-treated horses and ESBL shedding, data for this calculation was based on a human study [24]. Estimating that $25 \%$ of horses on admission are ESBL shedders (representing the equine community) and that $72 \%$ 
and $44 \%$ of horses were treated with antimicrobials within shedders and non-shedders, respectively, with a $5 \%$ significance level and power of $80 \%$, the total required sample size is 145 horses, including 116 non-shedders and 29 shedders.

Risk assessment was performed using Chi-square or Fisher's exact tests for association between individual variables, shedding and ESBL-E acquisition. Descriptive statistics were used to describe shedding rates. Continuous variables were analyzed using t-tests or Mann-Whitney U-tests. $p \leq 0.05$ was considered statistically significant. For risk factor analysis of farm horses, a logistic regression model (multivariable analysis) was conducted using all the significant variables in the univariable analysis at a significance level of $p<0.2$ using the ENTER method (IBM SPSS Statistics 25). Categorical data were summarized by the number of cases (percentage) and confidence intervals (95\%) were calculated by Fisher's (WinPEPI 11.15 Describe A).

In order to compare between shedding rates and antibiotic resistance rates within horses on admission and during hospitalization (cohorts (ii) and (iii), respectively), a mixed effect logistic regression model was conducted (STATA version 13). Resistance was defined as complete resistance (not including "intermediate resistance"). Odds ratio (OR) for a significant change in antibiotic resistance rates is defined as OR for a change in one resistance category (e.g., a change from "susceptible" to "intermediate" or from "intermediate" to "resistant"). A comparison between shedding rates and antibiotic resistance rates between farm horses (cohort (i)) and horses on admission (cohort (ii)) was performed using Chi-square.

\section{Results}

\subsection{Characterization of the Equine Study Populations (Table 1)}

Overall, 192 horses were sampled, originating from 13 farms across Israel (June 2016-September 2018). The average number of sampled horses per farm was 15 (range: 3-26 horses).

On admission, 168 horses were sampled (November 2015 to April 2016). Horses were admitted to hospitalization due to the following reasons: gastro-intestinal pathologies $(33 \%, n=55 / 168)$, orthopedic disorders $(17 \%, n=29 / 168)$, healthy (mares of sick neonatal foals or foals of sick mares, $17 \%, n=29 / 168)$, reproduction disorders $(12 \%, n=20 / 168)$, neonatology disorders $(12 \%, n=20 / 168)$, respiratory disorders $(4 \%, n=7 / 168)$, and others (including ophthalmic, hematology, endocrine, teeth disorders, and tumors, $5 \%, n=8 / 168$ ). The median length of illness before admission was one day (range: several hours-750 d). Horses hospitalized for $\geq 72 \mathrm{~h}$ were re-sampled $(\mathrm{n}=86)$.

Table 1. Characterization of farm horses versus horses on admission to hospital.

\begin{tabular}{|c|c|c|c|}
\hline Equine Cohort & Breeds $^{1}$ & Median Age $^{2}($ Years \pm SD $)$ & Sex Distribution ${ }^{3}$ \\
\hline Farm horses $(n=192)$ & $\begin{array}{c}41.1 \% \text { Arabians }(\mathrm{n}=79 / 192) \\
25 \% \text { pacers }(\mathrm{n}=48 / 192) \\
15.1 \% \text { Quarter horses }(\mathrm{n}=29 / 192) \\
9.9 \% \text { Warmbloods }(\mathrm{n}=19 / 192) \\
5.2 \% \text { local breed }(\mathrm{n}=10 / 192) \\
3.7 \% \text { ponies }(\mathrm{n}=7 / 192)\end{array}$ & $8 \pm 5.3$ & $\begin{array}{l}\text { mares }(72.4 \%, \mathrm{n}=139 / 192) \\
\text { geldings }(12.5 \%, \mathrm{n}=24 / 192) \\
\text { stallions }(11.5 \%, \mathrm{n}=22 / 192)^{4}\end{array}$ \\
\hline $\begin{array}{l}\text { Horses on admission } \\
\qquad(\mathrm{n}=168)\end{array}$ & $\begin{array}{c}\text { 49.4\% Arabians }(\mathrm{n}=83 / 168) \\
19.6 \% \text { Quarter horses }(\mathrm{n}=33 / 168) \\
14.3 \% \text { pacers }(\mathrm{n}=24 / 168) \\
7.7 \% \text { Friesians }(\mathrm{n}=13 / 168) \\
4.8 \% \text { Warmbloods }(\mathrm{n}=8 / 168) \\
4.2 \% \text { others }(\mathrm{n}=7 / 168)\end{array}$ & $4.5 \pm 5.2$ & $\begin{array}{l}\text { mares }(68.5 \%, \mathrm{n}=115 / 168) \\
\text { geldings }(16.1 \%, \mathrm{n}=27 / 168) \\
\text { stallions }(15.4 \%, \mathrm{n}=26 / 168)\end{array}$ \\
\hline
\end{tabular}

\footnotetext{
${ }^{1}$ Breed distribution was not significantly different for Arabians, Quarter horses, and Warmbloods in comparison to farm horses, and was significantly different for the pacers horses (significantly higher in farms, $p=0.012$ ) and Friesians (significantly higher on admission, $p<0.001$ ); ${ }^{2}$ Median age of horses on admission was significantly lower than the median age of farm horses $(p<0.0001) ;{ }^{3}$ Sex distribution was not significantly different between farm horses and horses on admission; ${ }^{4}$ Data was not available for seven horses.
}

\subsection{Antibiotic Therapy, Surgical Procedures, Length of Stay, and Outcome}

A proportion of $8.3 \%(n=16 / 192)$ of farm horses was hospitalized within the previous year, ranging from $0-30 \%$ between farms. A proportion of $19.8 \%(n=38 / 192)$ of horses were treated with antibiotics 
within the previous year, ranging from 0-61\% between farms. On admission, 9.5\% $(\mathrm{n}=16 / 168)$ of horses were reported to be previously hospitalized (within a year period), and $16.1 \%(n=27 / 168)$ of horses were treated with antibiotics within the previous year. Previous hospitalization and antibiotic treatment prevalence rates were not significantly different in comparison with farm horses.

During hospitalization, $50.6 \%$ of horses $(n=85 / 168)$ were treated with antibiotics, a proportion which is significantly higher than antibiotic treatment in farms and prior to admission $(p<0.0001)$. Surgical procedures were performed in $36.9 \%$ of horses $(n=62 / 168)$. The median length of stay was three days (range: several hours-21 d). Out of all horses admitted to hospitalization, $84.4 \%$ survived to discharge $(n=142 / 168)$.

\subsection{Prevalence of ESBL-E Shedding}

Within farm horses, shedding rate was 20.8\% [ $n=40 / 192,95 \%$ Confidence interval (CI) 15.3-27.3\%, Table 1]. Shedding rate on admission was $19.6 \%(n=33 / 168,95 \%$ CI: $13.9-26.5 \%)$, which was not statistically different from shedding rate in farms $(p=0.79)$. Shedding rate of hospitalized horses (re-sampled) was 77.9\% ( $\mathrm{n}=67 / 86,95 \%$ CI 67.7-86.1\%), which was significantly higher than the shedding rate on admission and in farms $(\mathrm{p}<0.001, \mathrm{OR}=12.12,95 \% \mathrm{CI} 3.92-37.49)$. Out of 67 hospitalized shedding horses, $77.6 \%(n=52 / 67,95 \%$ CI 65.8-86.9\%) did not shed ESBL-E on admission.

\subsection{Distribution of ESBL-E Species and ESBL Genes}

Overall, 192 ESBL-E isolates were analyzed (Table A1). Fourteen bacterial species were identified of which three were identified in all cohorts-E. coli, Klebsiella pneumoniae, and Enterobacter cloacae (Figure 1). The most prevalent bacterial species in all cohorts was E. coli, consisting of $79.2 \%$ of isolates from farms, $66.7 \%$ from horses on admission, and $49.0 \%$ from hospitalized horses. However, the prevalence of $E$. coli decreased in horses on admission and in hospitalized horses, as the diversity of other ESBL-E species increased, from four species in farms to five species on admission and twelve species in hospitalized horses. Nosocomial ESBL-E species that were not identified in farms and on admission included Citrobacter freundii $(\mathrm{n}=3 / 105)$, Salmonella spp $(\mathrm{n}=3 / 105)$, K. oxytoca, Citrobacter brakii, E. vulneris, Pantoea spp, Proteus mirabilis, and Raoultella ornithinolytica ( $\mathrm{n}=1 / 105$ each). The pandemic hypervirulent E. coli ST131 [25] was identified in three horses: two horses on admission and one horse during hospitalization. The main ESBL gene was the blaCTX-M-1 group in all cohorts (total 56.8\% of all isolates, Table 2).

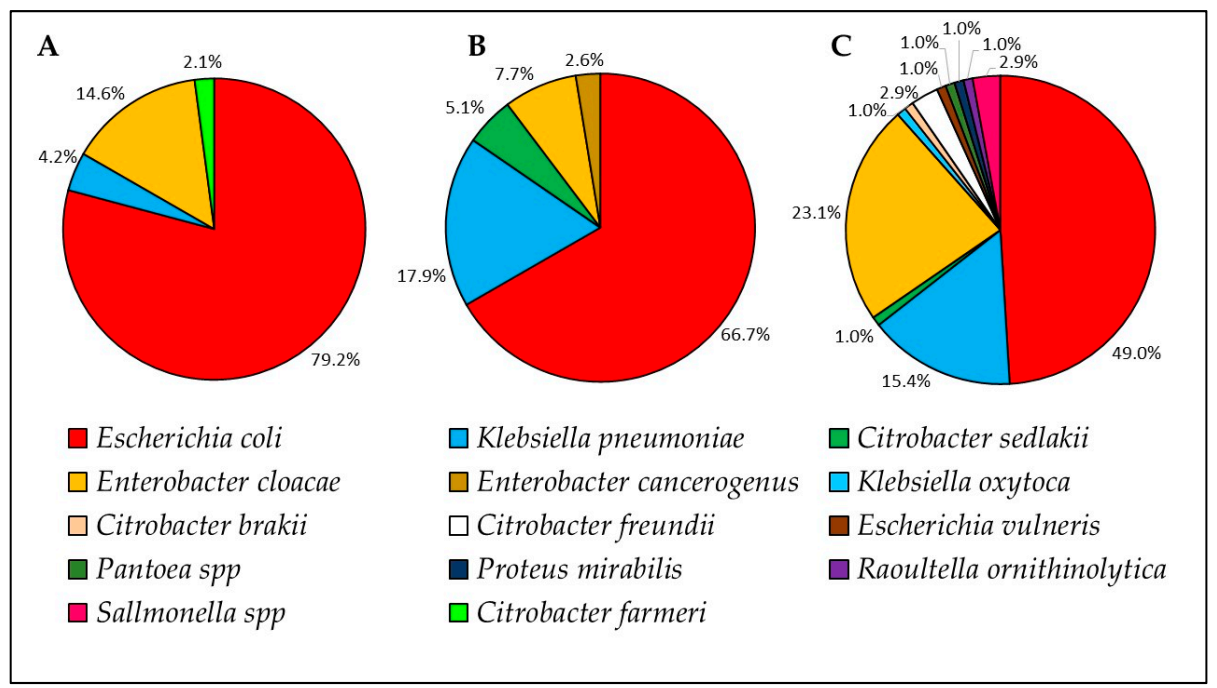

Figure 1. ESBL-E species distribution isolated from cohort (i) farm horses ((A), $n=48$ isolates), cohort (ii) horses on admission to the hospital ((B), $\mathrm{n}=39$ isolates) and cohort (iii) $72 \mathrm{~h}$ post-admission $((\mathbf{C})$, $\mathrm{n}=105$ isolates). 
Table 2. Shedding rates of extended-spectrum beta-lactamase-producing Enterobacteriaceae (ESBL-E) in farm horses, on admission, and during hospitalization.

\begin{tabular}{|c|c|c|c|c|}
\hline Equine Cohort & Shedding $(\%)$ & $\begin{array}{c}\text { Total No. of } \\
\text { ESBL-E Isolates }\end{array}$ & MDR Isolates (\%) & blaESBL Gene Group (\%) \\
\hline Farm horses & $\begin{array}{c}40 / 192(20.8) \\
(95 \% \text { CI: } 15.3-27.3 \%)\end{array}$ & 48 & $\begin{array}{c}43 / 48(89.6) \\
(95 \% \text { CI: 77.3-96.5) }\end{array}$ & $\begin{array}{c}\text { CTX-M-1: 35/48 (72.9) } \\
\text { CTX-M-9: 1/48 (2.1) } \\
\text { CTX-M-25: 1/48 (2.1) } \\
\text { SHV-12: 5/48 (10.4) }\end{array}$ \\
\hline Horses on admission & $\begin{array}{c}33 / 168(19.6) \\
(95 \% \text { CI: } 13.9-26.5 \%)\end{array}$ & 39 & $\begin{array}{c}28 / 39(71.8) \\
(95 \% \text { CI: } 55.1-85.0 \%)\end{array}$ & $\begin{array}{c}\text { CTX-M-1: } 24 / 39(61.5) \\
\text { CTX-M-9: } 1 / 39(2.5) \\
\text { SHV-12: } 3 / 39(7.7) \\
\text { SHV-2: } 1 / 39(2.5) \\
\text { SHV-28: } 1 / 39(2.5)\end{array}$ \\
\hline $\begin{array}{l}\text { Hospitalized horses } \\
(72 \mathrm{~h} \text { post admission })^{1}\end{array}$ & $\begin{array}{c}67 / 86(77.9)^{2} \\
(95 \% \text { CI } 67.7-86.1 \%)\end{array}$ & 105 & $\begin{array}{c}99 / 105(94.3) \\
(95 \% \text { CI: } 87.9-97.9 \%)^{3}\end{array}$ & $\begin{array}{c}\text { CTX-M-1: 50/105 (47.6) } \\
\text { CTX-M-2: 8/105 (7.6) } \\
\text { CTX-M-9: 7/105 (6.7) } \\
\text { CTX-M-25: 1/105 (0.95) } \\
\text { OXA-1: 2/105 (1.9) } \\
\text { SHV-12: 26/105 (24.7) } \\
\text { SHV-228: 1/105 (0.95) }\end{array}$ \\
\hline
\end{tabular}

${ }^{1}$ Horses re-sampled from cohort "horses on admission"; ${ }^{2}$ Shedding rate in hospitalized horses is significantly higher than shedding rate on admission and in farms $\left(p<0.0001, \mathrm{OR}=12.12,95 \%\right.$ CI 3.92-37.49); ${ }^{3}$ Prevalence of multidrug-resistant (MDR) isolates is significantly higher in isolates originated from hospitalized horses compared to isolates originated from horses on admission $(p<0.001)$.

\subsection{Antibiotic Susceptibility Profiles}

Antibiotic resistance rates varied between cohorts, with a significant increase during hospitalization. All isolates from all cohorts were susceptible to imipenem (Table 3).

Table 3. Antibiotic ${ }^{1}$ resistance rates (percentage) of ESBL-E isolates shed by farm horses, horses on admission, and hospitalized horses.

\begin{tabular}{cccccccccccc}
\hline Equine Cohort & AMP & AMC $^{2}$ & LEX & CAZ & IMP & CHL $^{3}$ & ENR $^{4}$ & AMK $^{\text {GEN }}$ & NIT $^{\mathbf{6}}$ & TMS $^{\mathbf{7}}$ \\
\hline Farms & 100 & 41.7 & 100 & 100 & 0 & 66.6 & 6.3 & 0 & 75 & 4.2 & 89.6 \\
\hline On admission & 100 & 82.1 & 100 & 85.0 & 0 & 46.2 & 17.9 & 2.6 & 48.7 & 5.3 & 76.3 \\
\hline $\begin{array}{c}\text { During } \\
\text { hospitalization }\end{array}$ & 96.0 & 32.0 & 99.0 & 90.0 & 0 & 85.3 & 51.5 & 10.8 & 84.3 & 11.0 & 95.0 \\
\hline
\end{tabular}

${ }^{1}$ Abbreviations: ampicillin (AMP), amoxicillin-clavulanate (AMC), cephalexin (LEX), ceftazidime (CAZ), imipenem (IMP), chloramphenicol (CHL), enrofloxacin (ENR), amikacin (AMK), gentamicin (GEN), nitrofurantoin (NIT), and Trimethoprim- sulpha (TMS); ${ }^{2}$ An increase in resistance rates for AMC on admission compared to farms ( $\left.p=0.001\right)$ and a decrease during hospitalization compared to admission $(p<0.001, \mathrm{OR}=0.1,95 \%$ CI $0.04,0.26){ }^{3}$ An increase in resistance rates for CHL during hospitalization compared to admission $(p<0.001$, OR $=6.5,95 \% \mathrm{CI} 2.8,15) ;{ }^{4} \mathrm{An}$ increase in resistance rates for ENR during hospitalization compared to admission $(p<0.001, \mathrm{OR}=4.2,95 \% \mathrm{CI} 1.9$, $9.5) ;{ }^{5}$ An increase in resistance rates for GEN during hospitalization compared to admission $(p<0.001$, OR $=12.3$, $95 \%$ CI 2.9, 52.5); ${ }^{6}$ An increase in resistance rates for NIT during hospitalization compared to admission $(p<0.001$, $\mathrm{OR}=3.7,95 \% \mathrm{CI} 1.4,9.5) ;{ }^{7}$ An increase in resistance rates for TMS during hospitalization compared to admission $(p<0.01, \mathrm{OR}=6,95 \%$ CI $1.9,19.4)$.

Among bacteria that grew on Chromagar ESBL plates, the prevalence of MDR bacteria was 89.6\%, $71.8 \%$, and $94.3 \%$ in farms, horses on admission, and hospitalized horses, respectively. The prevalence rate was significantly higher in isolates originated from hospitalized horses compared to horses on admission $(p=0.001$, Table 2$)$.

\subsection{Risk Factor Analysis for ESBL-E Shedding}

\subsubsection{Farm Horses}

In univariable analysis, horses' breed, sex, hospitalization in the previous year, antibiotic treatment in the previous year, and age were significantly associated with ESBL-E shedding (Table A2). Since the Arabian breed was the most prevalent breed sampled, we clustered all other breeds as one category in the multivariable analysis. In a logistic regression model, the breed (Arabian), sex (stallion versus mare, 
which was the reference in this category), and antibiotic treatment in the previous year were identified as risk factors for shedding. Age greater than one year was identified as a protective factor (Table 4).

Table 4. Risk factor analysis for ESBL-E shedding by farm horses (logistic regression model).

\begin{tabular}{ccc}
\hline Variable & $p$-value & Odds Ratio (95\% CI) \\
\hline Breed (Arabian versus non-Arabian) & 0.006 & $3.9(1.5-10.4)$ \\
\hline Sex (reference: mare) & 0.079 & - \\
\hline Stallion & 0.029 & $3.4(1.1-12.2)$ \\
\hline Gelding & 0.744 & $0.7(0.07-6.4)$ \\
\hline Age & 0.008 & $0.9(0.8-0.97)$ \\
\hline Hospitalization within the previous year & 0.194 & $2.9(0.6-14.8)$ \\
\hline Antibiotic treatment within the previous year & $<0.0001$ & $9.8(3.6-26.8)$ \\
\hline
\end{tabular}

\subsubsection{Horses on Admission}

Signalment (age, sex, and breed), geographic origin, prior hospitalizations in the last year, clinical signs, length of illness before admission, antibiotic therapy before and during hospitalization, surgical procedures, other medications, hospitalization length, short-term outcome, and admission charge were not associated with ESBL-E shedding on admission (Table A2). Sex, hospitalization length, and admission charge resulted in $p<0.2$, therefore, were analyzed via a logistic regression model, which did not yield any significant associations (Table A3).

\subsubsection{Horses During Hospitalization}

There was no association between ESBL shedding $72 \mathrm{~h}$ post-admission and on admission, clinical signs on admission, antibiotic treatment during hospitalization, surgical procedures during hospitalization, length of stay, admission charge and outcome (Table A2).

\section{Discussion}

This study investigates ESBL-E shedding in three equine cohorts, including farm horses, representing community equine, as well as horses on admission to the hospital and during hospitalization. Studies regarding antibiotic-resistant pathogens shedding, either in farm horses or in hospitalized horses were reported previously from different European countries [13,22,26,27]. Our study compares different equine cohorts within the same country. Both community and hospital cohorts are of great interest, from a veterinary and a 'one health' perspective, therefore it is highly valuable to compare these cohorts.

We found high ESBL-E shedding rates (Table 2), an increased bacterial species diversity (Figure 1) as well as in the ESBL-E genes variety (Table 2). An increase in shedding rates may be due to the acquisition of bacteria, plasmids or resistance genes. The main bacterial species in all cohorts was E. coli, with decreased incidence on admission and during hospitalization, due to increased incidence of other nosocomial ESBL-producing bacterial species. The main ESBL gene group was CTX-M-1, as was previously reported in community horses [26]. However, on admission and during hospitalization, CTX-M-1 incidence decreases, alongside an increase in the number of ESBL genes. A study conducted in an equine hospital in the UK demonstrated the emergence of ESBL-producing E. coli during a decade [26], whereas we demonstrated a significant increase in ESBL-E shedding during individual horses' hospitalization. These findings support an urgent necessity in active surveillance and infection control programs in veterinary facilities and hospitals.

In addition, there is a need to set strict antibiotic stewardship programs in veterinary medicine, specifically in companion animals' facilities, with specific guidance and enforcement. According to a recommendation published by the Committee for Medicinal Products for Veterinary Use (CVMP) 
of the European Union, there is a need to reserve fluoroquinolones, third and fourth generation cephalosporins for treatment when other options are likely to fail, and whenever possible, treatment should be supported by an antimicrobial susceptibility testing [28]. In practice, fluoroquinolones and cephalosporins are in use in equine medicine, sometimes as a first-line choice [29,30]. In our study, ESBL-E shedding as well as resistance rates for chloramphenicol, enrofloxacin, gentamicin, nitrofurantoin, and trimethoprim-sulpha increased significantly during hospitalization, resulting in a significant increase in MDR bacterial species shedding (Tables 2 and 3). In light of our findings, as well as increasing resistance rates in other equine studies, we recommend implementing antibiotic stewardships in equine clinics and hospitals [31,32].

We also aimed to determine risk factors for shedding. We did not find significant associations between shedding on admission and during hospitalization to medical data. During the study period, we sampled all horses on admission, which represented a heterogeneous population, including critically ill horses alongside healthy mares, which were hospitalized together with their sick foals. Therefore, the lack of significant risk factors may be due to high variation in the equine population. Many of the pathologies on admission were attributed to the gastro-intestinal system, which might influence the intestinal microbiome. However, clinical signs on admission and during hospitalization were not associated with shedding. In farm horses, we detected several risk factors for ESBL-E shedding (Table 4). The Arabian breed was the main breed within farm horses and horses on admission to hospital. These horses in Israel are used mainly for breeding and shows and are held under intensive management, which may explain the risk for ESBL shedding. Interestingly, we detected the 'stallion' sex as a risk factor. In human medicine, it is reported that males are more susceptible to diverse bacterial illnesses than females, including an ESBL-E infection [33], presumably related to hormonal influences [34]. This may explain also our findings in veterinary medicine, however, it requires further investigation. Previous antibiotic treatment was identified as a risk factor as well, in agreement with other human and veterinary studies [2,13]. Age older than one year was identified as a protective factor, which may be due to the maturation of immunity. In a national survey of cattle farms in Israel, the prevalence of ESBL-E was higher in calves versus adult cows, where the use of antimicrobial prophylaxis was more common [35]. In human medicine, elderly age is associated with ESBL-E infections [33]. However, in our study, elderly horses older than 20 years old [36] were not prevalent and consisted of $3 \%(n=12 / 360)$ of the study population. Therefore, elderly age may not be identified as a risk factor.

Our results should also be addressed from a 'one health' perspective. We detected resistant zoonotic bacteria both in farms and in hospital settings, which underlines the necessity for awareness and improved management. The human-animal interaction has great psychological and physical established benefits, with a great emphasis on equine-assisted therapy [37-39]. Therefore, there is pronounced importance in establishing safety policies involving therapists, physicians, and veterinarians, in order to ensure safe human-equine interactions in community settings [40]. This also applies to veterinary hospital staff. In a longitudinal study involving veterinary hospital staff and students, a higher level of ESBL-producing E. coli carriage was observed longitudinally [41], which underlines the necessity to implement gold standards biosecurity programs in veterinary hospitals.

\section{Conclusions}

Multi-drug resistant potentially zoonotic bacteria were detected both in farm horses and in hospitalized horses, with a significantly increased shedding during hospitalization. Therefore, we recommend implementing active surveillance programs alongside with infection control and antibiotic stewardship policies, in order to decrease resistance burden and to allow safe human-equine interactions. 
Author Contributions: Conceptualization, A.S.-T., S.N.-V. and A.S.; methodology, S.N.-V. A.S., W.A.A, Y.P. and H.A.; software, W.A.A.; validation, A.S.-T., S.N.-V. and A.S.; formal analysis, A.S.-T., Z.D., Y.P. and H.A.; investigation, A.S.-T.; resources, S.N.-V., A.S., M.F., Y.P., G.K.; data curation, A.S.-T.; writing-original draft preparation, A.S.-T., S.N.-V. and A.S.; writing-review and editing, all authors; visualization, all authors; supervision, S.N.-V. and A.S.; project administration, A.S.-T., S.N.-V. and A.S.; funding acquisition, S.N.-V. and A.S. All authors have read and agreed to the published version of the manuscript.

Funding: This research received no external funding.

Acknowledgments: We are grateful to the KSVM-VTH equine department staff, farm owners, employees, and veterinarians for their collaboration in conducting this study.

Conflicts of Interest: The authors declare no conflict of interest. 


\section{Appendix A}

Table A1. Antimicrobial susceptibility profiles of individual isolates.

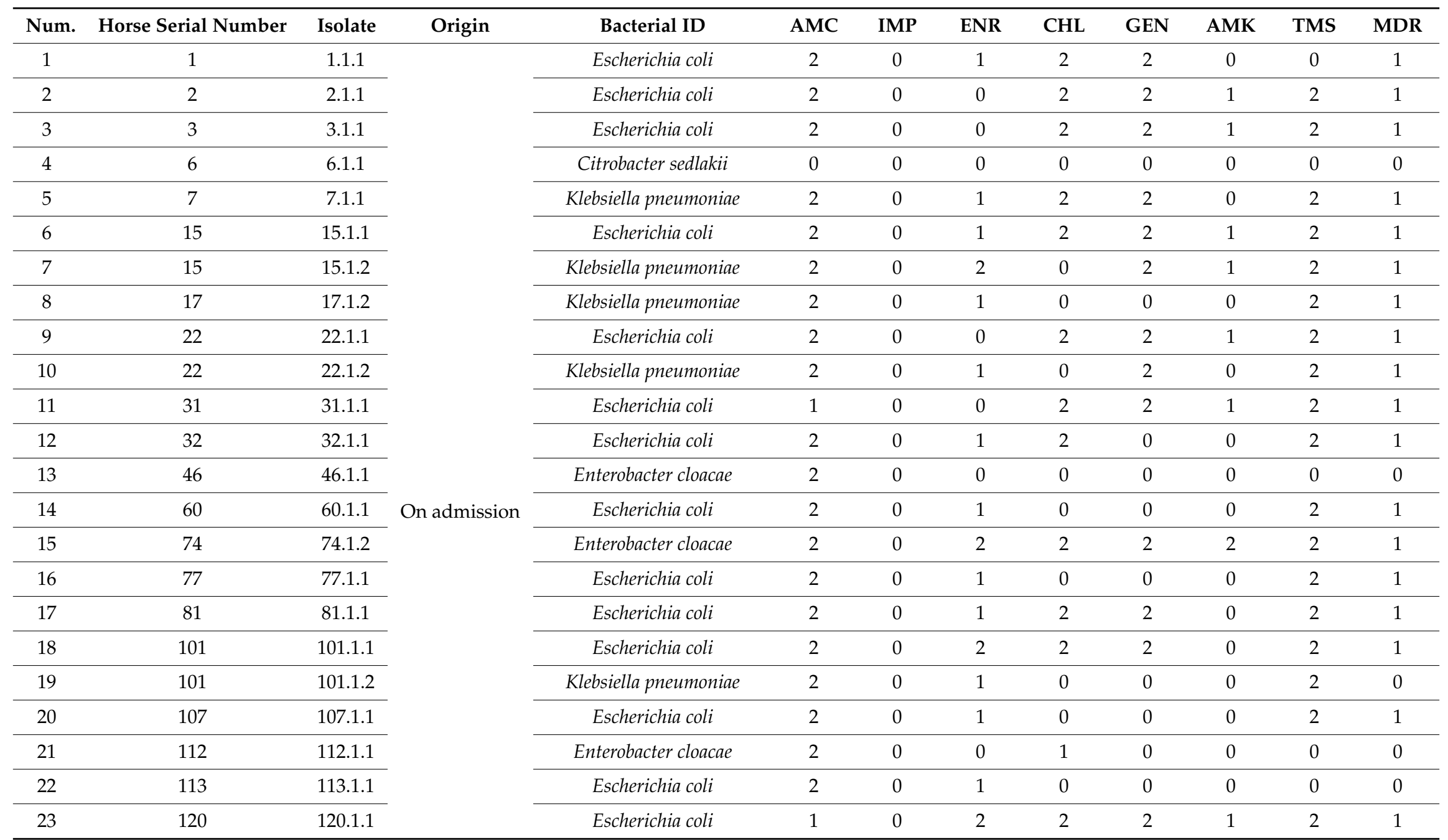


Table A1. Cont.

\begin{tabular}{|c|c|c|c|c|c|c|c|c|c|c|c|c|}
\hline Num. & Horse Serial Number & Isolate & Origin & Bacterial ID & AMC & IMP & ENR & CHL & GEN & AMK & TMS & MDR \\
\hline 24 & 121 & 121.1.1 & & Escherichia coli & 2 & 1 & 2 & 2 & 0 & 0 & 0 & 1 \\
\hline 25 & 136 & 136.1.1 & & Escherichia coli & 2 & 0 & 2 & 2 & 0 & 0 & 2 & 1 \\
\hline 27 & 144 & 144.1.1 & & Escherichia coli & 2 & 0 & 1 & 2 & 2 & 1 & 2 & 1 \\
\hline 28 & 153 & 153.1.1 & & Escherichia coli & 2 & 0 & 1 & 0 & 0 & 0 & 2 & 0 \\
\hline 29 & 162 & 162.1.1 & & Escherichia coli & 2 & 0 & 0 & 0 & 0 & 1 & 0 & 1 \\
\hline 30 & 176 & 176.1.1 & & Escherichia coli & 2 & 0 & 1 & 2 & 2 & 1 & 2 & 1 \\
\hline 31 & 177 & 177.1.1 & & Escherichia coli & 1 & 0 & 1 & 2 & 2 & 0 & 2 & 1 \\
\hline 32 & 179 & 179.1.1 & & Escherichia coli & 1 & 0 & 0 & 2 & 2 & 0 & 2 & 1 \\
\hline 33 & 203 & 203.1.1 & & Klebsiella pneumoniae & 0 & 0 & 0 & 0 & 2 & 0 & 0 & 0 \\
\hline 34 & 239 & 239.1 .1 & & Enterobacter cancerogenus & 2 & 0 & 0 & 0 & 0 & 0 & 0 & 0 \\
\hline 35 & 244 & 244.1.1 & & Citrobacter sedlakii & & 0 & 0 & 0 & 0 & 0 & & 0 \\
\hline 36 & 267 & 267.1 .1 & & Escherichia coli & 2 & 0 & 1 & 0 & 0 & 0 & 2 & 1 \\
\hline 37 & 278 & 278.1.1 & & Escherichia coli & 2 & 0 & 1 & 0 & 0 & 0 & 2 & 1 \\
\hline 38 & 288 & 288.1 .1 & & Escherichia coli & 2 & 0 & 1 & 0 & 0 & 0 & 2 & 1 \\
\hline 39 & 290 & 290.1 .1 & & Escherichia coli & 2 & 0 & 1 & 0 & 0 & 0 & 2 & 1 \\
\hline 40 & 1 & 1.2 .2 & & Klebsiella pneumoniae & 0 & 0 & 1 & 0 & 2 & 0 & 2 & 1 \\
\hline 41 & 5 & 5.2 .1 & & Escherichia coli & 0 & 0 & 0 & 2 & 2 & 0 & 2 & 1 \\
\hline 42 & 6 & 6.2 .1 & & Klebsiella pneumoniae & 1 & 0 & 2 & 0 & 0 & 0 & 2 & 1 \\
\hline 43 & 6 & 6.2 .2 & & Escherichia coli & 0 & 0 & 0 & 0 & 0 & 0 & 2 & 0 \\
\hline 44 & 7 & 7.2 .1 & & Escherichia coli & 1 & 0 & 0 & 0 & 2 & 0 & 2 & 1 \\
\hline 45 & 7 & 7.2 .2 & & Klebsiella pneumoniae & 1 & 0 & 2 & 2 & 2 & 0 & 2 & 1 \\
\hline
\end{tabular}


Table A1. Cont.

\begin{tabular}{|c|c|c|c|c|c|c|c|c|c|c|c|c|}
\hline Num. & Horse Serial Number & Isolate & Origin & Bacterial ID & AMC & IMP & ENR & CHL & GEN & AMK & TMS & MDR \\
\hline 46 & 8 & 8.2 .1 & & Escherichia coli & 2 & 0 & 1 & 2 & & & 2 & 1 \\
\hline 47 & 8 & 8.2 .2 & & Enterobacter cloacae & 2 & 0 & 2 & 2 & 2 & 0 & 2 & 1 \\
\hline 48 & 15 & 15.2 .1 & & Escherichia coli & 1 & 0 & 2 & 2 & 2 & 0 & 2 & 1 \\
\hline 49 & 15 & 15.2 .2 & & Enterobacter cloacae & 2 & 0 & 1 & 2 & 2 & 0 & 2 & 1 \\
\hline 50 & 16 & 16.2 .1 & & Escherichia coli & 0 & 0 & 1 & 2 & 0 & 0 & 2 & 1 \\
\hline 51 & 16 & 16.2 .2 & & Enterobacter cloacae & 2 & 0 & 2 & 2 & 2 & 0 & 2 & 1 \\
\hline 52 & 29 & 29.2 .1 & & Escherichia coli & 1 & 0 & 2 & 2 & 2 & 0 & 2 & 1 \\
\hline 53 & 29 & 29.2 .2 & & Escherichia vulneris & 0 & 0 & 1 & 2 & 2 & 0 & 2 & 1 \\
\hline 54 & 31 & 31.2 .1 & & Escherichia coli & 1 & 0 & 2 & 2 & 2 & 0 & 2 & 1 \\
\hline 55 & 35 & 35.2 .1 & & Klebsiella pneumoniae & 1 & 0 & 1 & 2 & 2 & 0 & 2 & 1 \\
\hline 56 & 46 & 46.2 .1 & & Pantoea spp & 1 & 0 & 2 & 2 & 2 & 0 & & 1 \\
\hline 57 & 46 & 46.2 .2 & & Escherichia coli & 1 & 0 & 2 & 2 & 2 & 0 & 2 & 1 \\
\hline 58 & 47 & 47.2.1 & & Escherichia coli & 1 & 0 & 2 & 2 & 2 & 0 & 2 & 1 \\
\hline 60 & 49 & 49.2 .2 & & Enterobacter cloacae & 2 & 0 & 1 & 2 & 2 & 2 & 2 & 1 \\
\hline 61 & 55 & 55.2 .1 & & Escherichia coli & 1 & & 1 & 2 & 2 & 0 & 2 & 1 \\
\hline 62 & 55 & 55.2 .2 & & Klebsiella pneumoniae & 1 & 0 & 2 & 0 & 2 & 0 & 2 & 1 \\
\hline 63 & 56 & 56.2 .2 & & Enterobacter cloacae & 2 & 0 & 2 & 2 & 2 & 1 & 2 & 1 \\
\hline 64 & 57 & 57.2 .1 & & Escherichia coli & 0 & 0 & & & 0 & 0 & 2 & 0 \\
\hline 65 & 60 & 60.2 .1 & & Enterobacter cloacae & 2 & 0 & 2 & 2 & 2 & 0 & 2 & 1 \\
\hline 66 & 60 & 60.2 .3 & & Escherichia coli & 1 & 0 & 1 & 2 & 2 & 0 & 2 & 1 \\
\hline 67 & 72 & 72.2 .3 & & Salmonella group & 1 & 0 & 0 & & 2 & 2 & 2 & 1 \\
\hline 68 & 75 & 75.2 .3 & & Enterobacter cloacae & 2 & 0 & 1 & 2 & 2 & 0 & 2 & 1 \\
\hline 69 & 84 & 84.2 .1 & & Escherichia coli & 0 & 0 & 0 & 2 & 2 & 0 & 2 & 1 \\
\hline
\end{tabular}


Table A1. Cont.

\begin{tabular}{|c|c|c|c|c|c|c|c|c|c|c|c|c|}
\hline Num. & Horse Serial Number & Isolate & Origin & Bacterial ID & AMC & IMP & ENR & CHL & GEN & AMK & TMS & MDR \\
\hline 70 & 85 & 85.2 .1 & & Escherichia coli & 0 & 0 & 1 & 2 & 2 & 0 & 2 & 1 \\
\hline 71 & 85 & 85.2 .2 & & Enterobacter cloacae & 2 & 0 & 2 & 2 & 2 & 0 & 2 & 1 \\
\hline 72 & 87 & 87.2 .1 & & Escherichia coli & 0 & 0 & 2 & 2 & 0 & 0 & 2 & 1 \\
\hline 73 & 87 & 87.2 .2 & & Escherichia coli & 1 & 0 & 2 & 2 & 2 & 0 & 2 & 1 \\
\hline 74 & 89 & 89.2 .1 & & Escherichia coli & 1 & 0 & 2 & 2 & 2 & 0 & 2 & 1 \\
\hline 75 & 89 & 89.2 .2 & & Klebsiella pneumoniae & 1 & 0 & 2 & 0 & 2 & 0 & 2 & 1 \\
\hline 76 & 91 & 91.2 .1 & & Escherichia coli & 1 & 0 & 2 & 2 & 2 & 2 & 2 & 1 \\
\hline 77 & 91 & 91.2 .2 & & Enterobacter cloacae & 2 & 0 & 2 & 2 & 2 & 0 & 2 & 1 \\
\hline 78 & 101 & 101.2.1 & & Escherichia coli & 1 & 0 & 2 & 2 & 1 & 0 & 2 & 1 \\
\hline 79 & 101 & 101.2.2 & & Klebsiella pneumoniae & 0 & 0 & 1 & 2 & 0 & 0 & 2 & 1 \\
\hline 80 & 107 & 107.2.1 & & Escherichia coli & 1 & 0 & 2 & 2 & 2 & 0 & 2 & 1 \\
\hline 81 & 107 & 107.2.2 & & Enterobacter cloacae & 2 & 0 & 2 & 2 & 2 & 2 & 2 & 1 \\
\hline 82 & 107 & 107.2.4 & & Enterobacter cloacae & 2 & 0 & 1 & 2 & 2 & 0 & 2 & 1 \\
\hline 83 & 108 & 108.2.2 & & Enterobacter cloacae & 2 & 0 & 1 & 2 & 2 & 0 & 2 & 1 \\
\hline 84 & 113 & 113.2.1 & & Escherichia coli & & & 2 & 2 & & & & \\
\hline 85 & 115 & 115.2.1 & & Escherichia coli & 0 & 0 & 2 & 2 & 2 & 0 & 2 & 1 \\
\hline 86 & 115 & 115.2 .2 & & Citrobacter freundii & 2 & 0 & 2 & 2 & 2 & 0 & 2 & 1 \\
\hline 87 & 124 & 124.2 .1 & & Escherichia coli & 0 & 0 & 2 & 2 & 2 & 0 & 2 & 1 \\
\hline 88 & 124 & 124.2 .3 & & Salmonella enterica & 1 & 0 & & & 2 & 2 & 2 & 1 \\
\hline 89 & 126 & 126.2 .2 & & Citrobacter brakii & 2 & 0 & 2 & 2 & 2 & 1 & 2 & 1 \\
\hline 90 & 127 & 127.2.1 & & Escherichia coli & 1 & 0 & 2 & 2 & 2 & 1 & 2 & 1 \\
\hline 91 & 127 & 127.2.2 & & Enterobacter cloacae & 2 & 0 & 1 & 2 & 2 & 0 & 2 & 1 \\
\hline 92 & 136 & 136.2 .1 & & Escherichia coli & 1 & 0 & 2 & 2 & 2 & 1 & 2 & 1 \\
\hline
\end{tabular}


Table A1. Cont.

\begin{tabular}{|c|c|c|c|c|c|c|c|c|c|c|c|c|}
\hline Num. & Horse Serial Number & Isolate & Origin & Bacterial ID & AMC & IMP & ENR & CHL & GEN & AMK & TMS & MDR \\
\hline 93 & 136 & 136.2 .2 & & Klebsiella pneumoniae & 1 & 0 & 2 & 0 & 2 & 0 & 2 & 1 \\
\hline 94 & 143 & 143.2 .1 & & Escherichia coli & 0 & 0 & 0 & 2 & 2 & 0 & 2 & 1 \\
\hline 96 & 144 & 144.2 .1 & & Escherichia coli & 2 & 0 & 1 & 2 & 2 & 0 & 2 & 1 \\
\hline 97 & 144 & 144.2 .2 & & Citrobacter freundii & 2 & 0 & & & 2 & 1 & 2 & 1 \\
\hline 98 & 144 & 144.2 .3 & & Proteus mirabilis & 1 & 0 & & & 2 & 0 & 0 & 1 \\
\hline 99 & 148 & 148.2 .1 & & Escherichia coli & 2 & 0 & 0 & 0 & 0 & 0 & 2 & 1 \\
\hline 100 & 149 & 149.2 .1 & & Escherichia coli & 0 & 0 & 0 & 2 & 2 & 0 & 2 & 1 \\
\hline 101 & 149 & 149.2 .2 & & Enterobacter cloacae & 2 & 0 & 1 & 2 & 2 & 2 & 2 & 1 \\
\hline 102 & 152 & 152.2 .2 & & Escherichia coli & 1 & 0 & 2 & 0 & 2 & 0 & 2 & 1 \\
\hline 103 & 156 & 156.2.1 & & Enterobacter cloacae & 2 & 0 & 1 & 2 & 2 & 2 & 2 & 1 \\
\hline 104 & 156 & 156.2.2 & & Escherichia coli & 1 & 0 & 2 & 2 & 2 & 0 & 2 & 1 \\
\hline 105 & 158 & 158.2.2 & & Klebsiella pneumoniae & 1 & 0 & 2 & 0 & 2 & 0 & 2 & 1 \\
\hline 106 & 161 & 161.2.1 & & Escherichia coli & 1 & 0 & 2 & 2 & 2 & 0 & 2 & 1 \\
\hline 107 & 161 & 161.2 .2 & & Enterobacter cloacae & 2 & 0 & 1 & 2 & 2 & 0 & 2 & 1 \\
\hline 108 & 167 & 167.2.1 & & Klebsiella pneumoniae & 1 & 0 & 1 & 2 & 2 & 0 & 2 & 1 \\
\hline 109 & 176 & 176.2.1 & & Escherichia coli & 1 & 0 & 0 & 2 & 2 & 0 & 2 & 1 \\
\hline 110 & 177 & 177.2.1 & & Escherichia coli & 1 & 0 & 1 & 2 & 2 & 0 & 2 & 1 \\
\hline 111 & 177 & 177.2 .2 & & Enterobacter cloacae & 2 & 0 & 1 & 2 & 2 & 0 & 2 & 1 \\
\hline 112 & 181 & 181.2.1 & & Enterobacter cloacae & 2 & 0 & 1 & & 2 & 1 & 2 & 1 \\
\hline 113 & 181 & 181.2 .2 & & Escherichia coli & 1 & 0 & 2 & 2 & 2 & 0 & 2 & 1 \\
\hline 114 & 183 & 183.2.1 & & Klebsiella pneumoniae & 1 & 0 & 1 & 2 & 2 & 0 & 2 & 1 \\
\hline 115 & 183 & 183.2.2 & & Escherichia coli & 1 & 0 & 0 & 2 & 2 & 0 & 2 & 1 \\
\hline
\end{tabular}


Table A1. Cont.

\begin{tabular}{|c|c|c|c|c|c|c|c|c|c|c|c|c|}
\hline Num. & Horse Serial Number & Isolate & Origin & Bacterial ID & AMC & IMP & ENR & CHL & GEN & AMK & TMS & MDR \\
\hline 116 & 195 & 195.2.1 & & Escherichia coli & 1 & 0 & 1 & 2 & 2 & 0 & 2 & 1 \\
\hline 117 & 212 & 212.2 .1 & & Escherichia coli & 0 & 0 & 1 & & 2 & 0 & 0 & 0 \\
\hline 118 & 216 & 216.2 .1 & & Escherichia coli & 0 & 0 & 2 & 2 & 0 & 0 & 2 & 0 \\
\hline 119 & 219 & 219.2 .1 & & Escherichia coli & 1 & 0 & 2 & & 2 & 0 & 2 & 1 \\
\hline 120 & 222 & 222.2 .1 & & Klebsiella pneumoniae & 1 & 0 & 1 & 2 & 2 & 0 & 2 & 1 \\
\hline 121 & 222 & 222.2 .2 & & Escherichia coli & 0 & 0 & 2 & 2 & 0 & 0 & 2 & 1 \\
\hline 122 & 223 & 223.2 .1 & & Escherichia coli & 1 & 0 & 2 & 2 & 2 & 0 & 0 & 1 \\
\hline 123 & 224 & 224.2 .1 & & Escherichia coli & 1 & 0 & 2 & 2 & 2 & 0 & 2 & 1 \\
\hline 124 & 224 & 224.2 .2 & & Klebsiella pneumoniae & 1 & 0 & 2 & 2 & 2 & 0 & 2 & 1 \\
\hline 125 & 228 & 228.2 .1 & & Klebsiella pneumoniae & 0 & 0 & 2 & 0 & 2 & 0 & 0 & 1 \\
\hline 126 & 229 & 229.2.1 & & Escherichia coli & 1 & 0 & 2 & 2 & 2 & 2 & 2 & 1 \\
\hline 127 & 229 & 229.2.2 & & Salmonella enterica & 1 & 0 & 2 & 2 & 2 & 2 & 2 & 1 \\
\hline 128 & 234 & 234.2.1 & & Raoultella ornithinolytica & 2 & 0 & 1 & 2 & 2 & 2 & 2 & 1 \\
\hline 129 & 237 & 237.2.1 & & Escherichia coli & 0 & 0 & 0 & 2 & 0 & 0 & 2 & 1 \\
\hline 130 & 238 & 238.2 .1 & & Klebsiella pneumoniae & 1 & 0 & 1 & 0 & 2 & 0 & 2 & 1 \\
\hline 131 & 243 & 243.2 .1 & & Escherichia coli & 0 & 0 & 2 & 2 & 0 & 0 & 2 & 1 \\
\hline 132 & 243 & 243.2 .2 & & Enterobacter cloacae & 2 & 0 & 1 & 2 & 2 & 0 & 2 & 1 \\
\hline 133 & 246 & 246.2 .1 & & Escherichia coli & 1 & 0 & & & 1 & 0 & 2 & 1 \\
\hline 134 & 246 & 246.2 .2 & & Enterobacter cloacae & 2 & 0 & 2 & 2 & 2 & 0 & 2 & 1 \\
\hline 135 & 265 & 265.2.1 & & Enterobacter cloacae & 2 & 0 & 1 & 2 & 2 & 0 & 2 & 1 \\
\hline 136 & 272 & 272.2 .1 & & Enterobacter cloacae & 2 & 0 & 1 & 2 & 2 & 0 & 2 & 1 \\
\hline 137 & 273 & 273.2.1 & & Enterobacter cloacae & 2 & 0 & 1 & 2 & 2 & 0 & 2 & 1 \\
\hline 138 & 278 & 278.2 .1 & & Escherichia coli & 0 & 0 & 1 & 2 & 0 & 0 & 2 & 1 \\
\hline
\end{tabular}


Table A1. Cont.

\begin{tabular}{|c|c|c|c|c|c|c|c|c|c|c|c|c|}
\hline Num. & Horse Serial Number & Isolate & Origin & Bacterial ID & AMC & IMP & ENR & CHL & GEN & AMK & TMS & MDR \\
\hline 139 & 278 & 278.2 .2 & & Citrobacter sedlakii & 0 & 0 & 2 & 2 & 0 & 0 & & 1 \\
\hline 140 & 278 & 278.2 .4 & & Klebsiella pneumoniae & 0 & 0 & 2 & 2 & 2 & 0 & 0 & 1 \\
\hline 142 & 279 & 279.2 .2 & & Escherichia coli & 0 & 0 & 1 & 2 & 0 & 0 & 2 & 1 \\
\hline 143 & 289 & 289.2.1 & & Escherichia coli & 1 & 0 & 2 & 0 & 2 & 0 & 2 & 1 \\
\hline 144 & $\mathrm{H} 40$ & H40.2 & \multirow{18}{*}{ Farms } & Escherichia coli & 2 & 0 & 1 & 0 & 0 & 0 & 2 & 1 \\
\hline 145 & $\mathrm{H} 42$ & $\mathrm{H} 42.1$ & & Escherichia coli & 2 & 0 & 1 & 2 & 2 & 1 & 2 & 1 \\
\hline 146 & $\mathrm{H} 44$ & H44.1 & & Escherichia coli & 2 & 0 & 1 & 2 & 2 & 1 & 2 & 1 \\
\hline 147 & $\mathrm{H} 45$ & $\mathrm{H} 45.2$ & & Citrobacter farmeri & 1 & 0 & 1 & 2 & 2 & 0 & 2 & 1 \\
\hline 148 & $\mathrm{H} 48$ & $\mathrm{H} 48.2$ & & Escherichia coli & 2 & 0 & 2 & 2 & 2 & 0 & 2 & 1 \\
\hline 149 & $\mathrm{H} 48$ & $\mathrm{H} 48.3$ & & Enterobacter cloacae & 2 & 0 & 1 & 2 & 2 & 1 & 2 & 1 \\
\hline 150 & $\mathrm{H} 53$ & H53.1 & & Escherichia coli & 2 & 0 & 1 & 0 & 0 & 0 & 2 & 1 \\
\hline 151 & $\mathrm{H} 53$ & H53.2 & & Enterobacter cloacae & 2 & 0 & 1 & 2 & 2 & 1 & 2 & 1 \\
\hline 152 & $\mathrm{H} 54$ & H54.1 & & Escherichia coli & 2 & 0 & 2 & 2 & 2 & 0 & 2 & 1 \\
\hline 153 & H56 & H56.1 & & Escherichia coli & 2 & 0 & 1 & 2 & 2 & 1 & 2 & 1 \\
\hline 154 & H56 & H56.2 & & Enterobacter cloacae & 2 & 0 & 1 & 2 & 2 & 1 & 2 & 1 \\
\hline 155 & $\mathrm{H} 57$ & H57.1 & & Enterobacter cloacae & 2 & 0 & 1 & 2 & 2 & 1 & 2 & 1 \\
\hline 156 & $\mathrm{H} 57$ & H57.2 & & Escherichia coli & 2 & 0 & 1 & 2 & 2 & 1 & 2 & 1 \\
\hline 157 & $\mathrm{H} 60$ & H60.2 & & Escherichia coli & 2 & 0 & 1 & 0 & 0 & 0 & 2 & 1 \\
\hline 158 & H110 & H110.1 & & Enterobacter cloacae & 2 & 0 & 0 & 0 & 0 & 0 & 0 & 0 \\
\hline 159 & H138 & H138.1 & & Escherichia coli & 2 & 0 & 0 & 0 & 0 & 0 & 0 & 1 \\
\hline 160 & $\mathrm{H} 140$ & H140.1 & & Escherichia coli & 2 & 0 & 0 & 2 & 2 & 1 & 2 & 1 \\
\hline 161 & $\mathrm{H} 154$ & H154.2 & & Klebsiella pneumoniae & 2 & 0 & 1 & 1 & 2 & 0 & 0 & 1 \\
\hline
\end{tabular}


Table A1. Cont.

\begin{tabular}{|c|c|c|c|c|c|c|c|c|c|c|c|c|}
\hline Num. & Horse Serial Number & Isolate & Origin & Bacterial ID & AMC & IMP & ENR & CHL & GEN & AMK & TMS & MDR \\
\hline 162 & $\mathrm{H} 157$ & H157.2 & & Klebsiella pneumoniae & 2 & 0 & 2 & 0 & 0 & 0 & 2 & 1 \\
\hline 163 & $\mathrm{H} 230$ & H230.1 & & Escherichia coli & 1 & 0 & 1 & 2 & 2 & 0 & 2 & 1 \\
\hline 165 & H231 & H231.1 & & Escherichia coli & 0 & 0 & 1 & 0 & 0 & 0 & 0 & 0 \\
\hline 166 & $\mathrm{H} 233$ & H233.1 & & Escherichia coli & 1 & 0 & 1 & 2 & 2 & 0 & 2 & 1 \\
\hline 168 & $\mathrm{H} 234$ & H234.1 & & Escherichia coli & 0 & 0 & 1 & 2 & 2 & 0 & 2 & 1 \\
\hline 169 & $\mathrm{H} 234$ & $\mathrm{H} 234.2$ & & Enterobacter cloacae & 2 & 0 & 1 & 2 & 2 & 0 & 2 & 1 \\
\hline 170 & H235 & H235.1 & & Escherichia coli & 1 & 0 & 1 & 2 & 2 & 0 & 2 & 1 \\
\hline 171 & $\mathrm{H} 236$ & H236.1 & & Escherichia coli & 0 & 0 & 1 & 2 & 2 & 0 & 2 & 1 \\
\hline 172 & $\mathrm{H} 237$ & H237.1 & & Escherichia coli & 1 & 0 & 1 & 2 & 2 & 0 & 2 & 1 \\
\hline 173 & $\mathrm{H} 238$ & H238.1 & & Escherichia coli & 0 & 0 & 1 & 2 & 2 & 0 & 2 & 1 \\
\hline 174 & $\mathrm{H} 241$ & H241.1 & & Escherichia coli & 1 & 0 & 1 & 2 & 2 & 0 & 2 & 1 \\
\hline 175 & $\mathrm{H} 242$ & H242.1 & & Escherichia coli & 1 & 0 & 1 & 2 & 2 & 0 & 2 & 1 \\
\hline 176 & $\mathrm{H} 243$ & H243.1 & & Escherichia coli & 1 & 0 & 1 & 2 & 2 & 0 & 2 & 1 \\
\hline 177 & H245 & H245.1 & & Escherichia coli & 1 & 0 & 1 & 2 & 2 & 0 & 2 & 1 \\
\hline 178 & $\mathrm{H} 246$ & H246.1 & & Escherichia coli & 1 & 0 & 1 & 2 & 2 & 0 & 2 & 1 \\
\hline 179 & $\mathrm{H} 247$ & H247.1 & & Escherichia coli & 0 & 0 & 1 & 2 & 2 & 0 & 2 & 1 \\
\hline 180 & $\mathrm{H} 248$ & H248.1 & & Escherichia coli & 0 & 0 & 1 & 2 & 2 & 0 & 2 & 1 \\
\hline 181 & $\mathrm{H} 250$ & H250.1 & & Escherichia coli & 0 & 0 & 1 & 2 & 2 & 0 & 2 & 1 \\
\hline 182 & H251 & H251.1 & & Escherichia coli & 0 & 0 & 1 & 2 & 2 & 0 & 2 & 1 \\
\hline 183 & $\mathrm{H} 253$ & H253.1 & & Escherichia coli & 0 & 0 & 1 & 2 & 2 & 0 & 2 & 1 \\
\hline 184 & $\mathrm{H} 254$ & H254.1 & & Escherichia coli & 0 & 0 & 1 & 2 & 2 & 0 & 2 & 1 \\
\hline 185 & $\mathrm{H} 256$ & H256.1 & & Escherichia coli & 0 & 0 & 1 & 0 & 0 & 0 & 2 & 1 \\
\hline
\end{tabular}


Table A1. Cont.

\begin{tabular}{|c|c|c|c|c|c|c|c|c|c|c|c|c|}
\hline Num. & Horse Serial Number & Isolate & Origin & Bacterial ID & AMC & IMP & ENR & CHL & GEN & AMK & TMS & MDR \\
\hline 186 & $\mathrm{H} 257$ & H257.1 & & Escherichia coli & 1 & 0 & 0 & 1 & 2 & 0 & 2 & 1 \\
\hline 187 & $\mathrm{H} 258$ & H258.1 & & Escherichia coli & 0 & 0 & 0 & 0 & 0 & 0 & 2 & 0 \\
\hline 188 & $\mathrm{H} 259$ & H259.1 & & Escherichia coli & 0 & 0 & 0 & 0 & 0 & 0 & 2 & 0 \\
\hline 189 & $\mathrm{H} 263$ & H263.1 & & Escherichia coli & 0 & 0 & 0 & 0 & 0 & 0 & 2 & 0 \\
\hline 190 & $\mathrm{H} 265$ & H265.1 & & Escherichia coli & 1 & 0 & 0 & 1 & 2 & 0 & 2 & 1 \\
\hline 191 & $\mathrm{H} 267$ & H267.1 & & Escherichia coli & 0 & 0 & 1 & 0 & 0 & 0 & 2 & 1 \\
\hline 192 & $\mathrm{H} 268$ & H268.1 & & Escherichia coli & 1 & 0 & 0 & 1 & 2 & 0 & 2 & 1 \\
\hline
\end{tabular}

Susceptible $=0$, intermediate susceptibility $=1$, resistant $=2$. Empty cells mean lack of susceptibility test results due to technical reasons. 
Table A2. Results of univariable analysis of variables gleaned from the medical records (horses on admission and during hospitalization) and owners' questionnaires (farm horses). Variables were evaluated for association with the outcome of ESBL-E shedding status of the individual animal.

\begin{tabular}{|c|c|c|c|}
\hline Population Studied & Variable & Classification & $p$-Value \\
\hline \multirow{7}{*}{ Farm horses } & Breed & $\begin{array}{l}\text { Quarter Horse } \\
\text { Arabian } \\
\text { Pacer } \\
\text { Warmblood } \\
\text { Pony } \\
\text { Local }\end{array}$ & $<0.0001$ \\
\hline & Sex & $\begin{array}{c}\text { Female } \\
\text { Male } \\
\text { Gelding }\end{array}$ & 0.027 \\
\hline & Farm & Numbered 1-13 & \\
\hline & $\begin{array}{l}\text { Hospitalization within the } \\
\text { previous year }\end{array}$ & Yes/No & 0.018 \\
\hline & $\begin{array}{l}\text { Antibiotic treatment within the } \\
\text { previous year }\end{array}$ & Yes/No & $<0.0001$ \\
\hline & Age & Ranged from $0.1-23 \mathrm{y}$ & $<0.0001$ \\
\hline & Time in farm & Ranged from $0-23 \mathrm{y}$ & 0.36 \\
\hline \multirow{6}{*}{ On admission } & Breed & $\begin{array}{c}\text { Quarter Horse } \\
\text { Arabian } \\
\text { Tennessee Walking horse } \\
\text { Friesian } \\
\text { Mangalarga Marchador } \\
\text { Warmblood } \\
\text { Thoroughbred } \\
\text { Miniature horse } \\
\text { Haflinger } \\
\text { Hannoverian } \\
\text { Single footed horse } \\
\text { Missouri Fox Trotter }\end{array}$ & 0.394 \\
\hline & Age & Years & 0.259 \\
\hline & Sex & $\begin{array}{l}\text { Female } \\
\text { Male } \\
\text { Gelding }\end{array}$ & 0.117 \\
\hline & $\begin{array}{l}\text { Geographical origin (within the } \\
\text { country) }\end{array}$ & $\begin{array}{l}\text { North } \\
\text { South } \\
\text { Center }\end{array}$ & 0.879 \\
\hline & $\begin{array}{l}\text { Hospitalization within the } \\
\text { previous year }\end{array}$ & Yes/No & 0.295 \\
\hline & Clinical signs on admission & $\begin{array}{l}\text { Gastro-intestinal disorder } \\
\text { Neonatology disorder } \\
\text { Ophthalmic disorder } \\
\text { Reproduction } \\
\text { Orthopedic disorder } \\
\text { Hematological disorder } \\
\text { Respiratory disorder } \\
\text { Endocrine disorder } \\
\text { Healthy (mares of sick } \\
\text { hospitalized foals) }\end{array}$ & 0.587 \\
\hline
\end{tabular}


Table A2. Cont.

\begin{tabular}{|c|c|c|c|}
\hline Population Studied & Variable & Classification & $p$-Value \\
\hline & $\begin{array}{l}\text { Length of illness before } \\
\text { admission }\end{array}$ & Days & 0.618 \\
\hline & $\begin{array}{l}\text { Antibiotic treatment within the } \\
\text { previous year }\end{array}$ & Yes/No & 0.587 \\
\hline & Length of stay & Days & 0.169 \\
\hline & Admission charge & - & 0.056 \\
\hline \multirow{6}{*}{$\begin{array}{c}\text { During } \\
\text { hospitalization }\end{array}$} & Shedding on admission & Yes/No & 0.9 \\
\hline & Clinical signs on admission & $\begin{array}{c}\text { Gastro-intestinal disorder } \\
\text { Neonatology disorder } \\
\text { Ophthalmic disorder } \\
\text { Reproduction } \\
\text { Orthopedic disorder } \\
\text { Hematological disorder } \\
\text { Respiratory disorder } \\
\text { Endocrine disorder } \\
\text { Tumor } \\
\text { Teeth lesion } \\
\text { Healthy (mares of sick } \\
\text { hospitalized foals) }\end{array}$ & 0.428 \\
\hline & $\begin{array}{l}\text { Antibiotic treatment during } \\
\text { hospitalization }\end{array}$ & Yes/No & 0.841 \\
\hline & Outcome & Discharged/Died & 0.174 \\
\hline & Length of stay & Days & 0.29 \\
\hline & Admission charge & - & 0.69 \\
\hline
\end{tabular}

Table A3. Risk factor analysis for ESBL-E shedding by horses on admission to hospital (logistic regression).

\begin{tabular}{ccc}
\hline Risk Factor & $p$-Value & OR \\
\hline Sex (reference: mare) & 0.647 & $0.571(95 \%$ CI 0.151-2.162) \\
Stallion & 0.409 & $0.765(95 \%$ CI 0.25-2.34) \\
Gelding & 0.639 & $1(95 \%$ CI 0.997-1) \\
\hline Length of stay & 0.766 & $1(95 \% 1-1)$ \\
\hline Admission charge & 0.184 &
\end{tabular}

\section{References}

1. Vo, A.T.T.; van Duijkeren, E.; Fluit, A.C.; Gaastra, W. Characteristics of extended-spectrum cephalosporin-resistant Escherichia coli and Klebsiella pneumoniae isolates from horses. Vet. Microbiol. 2007, 124, 248-255. [CrossRef]

2. Paterson, D.L.; Bonomo, R.A. Extended-Spectrum $\beta$-Lactamases: A Clinical Update. Clin. Microbiol. Rev. 2005, 18, 657-686. [CrossRef]

3. Denkel, L.A.; Schwab, F.; Kola, A.; Leistner, R.; Garten, L.; von Weizsäcker, K.; Geffers, C.; Gastmeier, P.; Piening, B. The mother as most important risk factor for colonization of very low birth weight (VLBW) infants with extended-spectrum $\beta$-lactamase-producing Enterobacteriaceae (ESBL-E). J. Antimicrob. Chemother. 2014, 69, 2230-2237. [CrossRef]

4. Schwaber, M.J.; Navon-Venezia, S.; Kaye, K.S.; Ben-Ami, R.; Schwartz, D.; Carmeli, Y. Clinical and economic impact of bacteremia with extended- spectrum-beta-lactamase-producing Enterobacteriaceae. Antimicrob. Agents Chemother. 2006, 50, 1257-1262. [CrossRef] 
5. $\quad$ Ewers, C.; Stamm, I.; Pfeifer, Y.; Wieler, L.H.; Kopp, P.A.; Schønning, K.; Prenger-Berninghoff, E.; Scheufen, S.; Stolle, I.; Günther, S.; et al. Clonal spread of highly successful ST15-CTX-M-15 Klebsiella pneumoniae in companion animals and horses. J. Antimicrob. Chemother. 2014, 69, 2676-2680. [CrossRef]

6. Ewers, C.; Bethe, A.; Stamm, I.; Grobbel, M.; Kopp, P.A.; Guerra, B.; Stubbe, M.; Doi, Y.; Zong, Z.; Kola, A.; et al. CTX-M-15-D-ST648 Escherichia coli from companion animals and horses: Another pandemic clone combining multiresistance and extraintestinal virulence? J. Antimicrob. Chemother. 2014, 69, 1224-1230. [CrossRef]

7. Shnaiderman-Torban, A.; Navon-Venezia, S.; Dahan, R.; Dor, Z.; Taulescu, M.; Paitan, Y.; Edery, N.; Steinman, A. CTX-M-15 Producing Escherichia coli Sequence Type 361 and Sequence Type 38 Causing Bacteremia and Umbilical Infection in a Neonate Foal. J. Equine Vet. Sci. 2020, 85, 102881. [CrossRef]

8. Shnaiderman-Torban, A.; Paitan, Y.; Arielly, H.; Kondratyeva, K.; Tirosh-Levy, S.; Abells-Sutton, G.; Navon-Venezia, S.; Steinman, A. Extended-Spectrum $\beta$-Lactamase-Producing Enterobacteriaceae in Hospitalized Neonatal Foals: Prevalence, Risk Factors for Shedding and Association with Infection. Animals 2019, 9, 600. [CrossRef]

9. Johns, I.; Verheyen, K.; Good, L.; Rycroft, A. Antimicrobial resistance in faecal Escherichia coli isolates from horses treated with antimicrobials: A longitudinal study in hospitalised and non-hospitalised horses. Vet. Microbiol. 2012, 159, 381-389. [CrossRef]

10. Dolejska, M.; Duskova, E.; Rybarikova, J.; Janoszowska, D.; Roubalova, E.; Dibdakova, K.; Maceckova, G.; Kohoutova, L.; Literak, I.; Smola, J.; et al. Plasmids carrying blaCTX-M-1 and qnr genes in Escherichia coli isolates from an equine clinic and a horseback riding centre. J. Antimicrob. Chemother. 2011, 66, 757-764. [CrossRef]

11. Maddox, T.W.; Clegg, P.D.; Diggle, P.J.; Wedley, A.L.; Dawson, S.; Pinchbeck, G.L.; Williams, N.J. Cross-sectional study of antimicrobial-resistant bacteria in horses. Part 1: Prevalence of antimicrobial-resistant Escherichia coli and methicillin-resistant Staphylococcus aureus. Equine Vet. J. 2012, 44, 289-296. [CrossRef]

12. Kaspar, U.; von Lützau, K.; Schlattmann, A.; Rösler, U.; Köck, R.; Becker, K. Zoonotic multidrug-resistant microorganisms among non-hospitalized horses from Germany. One Health 2019, 7, 100091. [CrossRef]

13. De Lagarde, M.; Larrieu, C.; Praud, K.; Schouler, C.; Doublet, B.; Sallé, G.; Fairbrother, J.M.; Arsenault, J. Prevalence, risk factors, and characterization of multidrug resistant and extended spectrum $\beta$-lactamase/AmpC $\beta$-lactamase producing Escherichia coli in healthy horses in France in 2015. J. Vet. Intern. Med. 2019, 33, 902-911. [CrossRef]

14. Maddox, T.W.; Pinchbeck, G.L.; Clegg, P.D.; Wedley, A.L.; Dawson, S.; Williams, N.J. Cross-sectional study of antimicrobial-resistant bacteria in horses. Part 2: Risk factors for faecal carriage of antimicrobial-resistant Escherichia coli in horses. Equine Vet. J. 2012, 44, 297-303. [CrossRef]

15. Murk, J.-L.A.N.; Heddema, E.R.; Hess, D.L.J.; Bogaards, J.A.; Vandenbroucke-Grauls, C.M.J.E.; Debets-Ossenkopp, Y.J. Enrichment broth improved detection of extended-spectrum-beta-lactamase-producing bacteria in throat and rectal surveillance cultures of samples from patients in intensive care units. J. Clin. Microbiol. 2009, 47, 1885-1887. [CrossRef]

16. Clinical and Laboratory Standards Institute (CLSI). Performance Standards for Antimicrobial Susceptibility Testing, 26th ed.; Clinical and Laboratory Standards Institute: Wayne, PA, USA, 2016.

17. Falagas, M.E.; Karageorgopoulos, D.E. Pandrug Resistance (PDR), Extensive Drug Resistance (XDR), and Multidrug Resistance (MDR) among Gram-Negative Bacilli: Need for International Harmonization in Terminology. Clin. Infect. Dis. 2008, 46, 1121-1122. [CrossRef]

18. Woodford, N.; Fagan, E.J.; Ellington, M.J. Multiplex PCR for rapid detection of genes encoding CTX-M extended-spectrum $\beta$-lactamases. J. Antimicrob. Chemother. 2006, 57, 154-155. [CrossRef]

19. Lin, S.-P.; Liu, M.-F.; Lin, C.-F.; Shi, Z.-Y. Phenotypic detection and polymerase chain reaction screening of extended-spectrum $\beta$-lactamases produced by Pseudomonas aeruginosa isolates. J. Microbiol. Immunol. Infect. 2012, 45, 200-207. [CrossRef]

20. Tofteland, S.; Haldorsen, B.; Dahl, K.H.; Simonsen, G.S.; Steinbakk, M.; Walsh, T.R.; Sundsfjord, A. Norwegian ESBL Study Group Effects of phenotype and genotype on methods for detection of extended-spectrum-beta-lactamase-producing clinical isolates of Escherichia coli and Klebsiella pneumoniae in Norway. J. Clin. Microbiol. 2007, 45, 199-205. [CrossRef] 
21. Johnson, J.R.; Clermont, O.; Johnston, B.; Clabots, C.; Tchesnokova, V.; Sokurenko, E.; Junka, A.F.; Maczynska, B.; Denamur, E. Rapid and Specific Detection, Molecular Epidemiology, and Experimental Virulence of the O16 Subgroup within Escherichia coli Sequence Type 131. J. Clin. Microbiol. 2014, 52, 1358-1365. [CrossRef]

22. Ahmed, M.O.; Clegg, P.D.; Williams, N.J.; Baptiste, K.E.; Bennett, M. Antimicrobial resistance in equine faecal Escherichia coli isolates from North West England. Ann. Clin. Microbiol. Antimicrob. 2010, 9, 12. [CrossRef]

23. Bilavsky, E.; Temkin, E.; Lerman, Y.; Rabinovich, A.; Salomon, J.; Lawrence, C.; Rossini, A.; Salvia, A.; Samso, J.V.; Fierro, J.; et al. Risk factors for colonization with extended-spectrum beta-lactamase-producing enterobacteriaceae on admission to rehabilitation centres. Clin. Microbiol. Infect. Off. Publ. Eur. Soc. Clin. Microbiol. Infect. Dis. 2014, 20, O804-O810. [CrossRef]

24. Shitrit, P.; Reisfeld, S.; Paitan, Y.; Gottesman, B.-S.; Katzir, M.; Paul, M.; Chowers, M. Extended-spectrum beta-lactamase-producing Enterobacteriaceae carriage upon hospital admission: Prevalence and risk factors. J. Hosp. Infect. 2013, 85, 230-232. [CrossRef]

25. Ewers, C.; Grobbel, M.; Stamm, I.; Kopp, P.A.; Diehl, I.; Semmler, T.; Fruth, A.; Beutlich, J.; Guerra, B.; Wieler, L.H.; et al. Emergence of human pandemic O25:H4-ST131 CTX-M-15 extended-spectrum- $\beta$-lactamase-producing Escherichia coli among companion animals. J. Antimicrob. Chemother. 2010, 65, 651-660. [CrossRef]

26. Isgren, C.M.; Edwards, T.; Pinchbeck, G.L.; Winward, E.; Adams, E.R.; Norton, P.; Timofte, D.; Maddox, T.W.; Clegg, P.D.; Williams, N.J. Emergence of carriage of CTX-M-15 in faecal Escherichia coli in horses at an equine hospital in the UK; increasing prevalence over a decade (2008-2017). BMC Vet. Res. 2019, 15, 268. [CrossRef]

27. Maddox, T.W.; Williams, N.J.; Clegg, P.D.; O’Donnell, A.J.; Dawson, S.; Pinchbeck, G.L. Longitudinal study of antimicrobial-resistant commensal Escherichia coli in the faeces of horses in an equine hospital. Prev. Vet. Med. 2011, 100, 134-145. [CrossRef]

28. European Medicines Agency. Available online: https:/www.ema.europa.eu/en/documents/scientificguideline/reflection-paper-risk-antimicrobial-resistance-transfer-companion-animals_en.pdf (accessed on 15 January 2015).

29. Dunkel, B.; Johns, I.C. Antimicrobial use in critically ill horses. J. Vet. Emerg. Crit. Care 2015, 25, 89-100. [CrossRef]

30. Norris, J.M.; Zhuo, A.; Govendir, M.; Rowbotham, S.J.; Labbate, M.; Degeling, C.; Gilbert, G.L.; Dominey-Howes, D.; Ward, M.P. Factors influencing the behaviour and perceptions of Australian veterinarians towards antibiotic use and antimicrobial resistance. PLoS ONE 2019, 14, e0223534.

31. Van Spijk, J.N.; Schmitt, S.; Schoster, A. Infections caused by multidrug-resistant bacteria in an equine hospital (2012-2015). Equine Vet. Educ. 2019, 31, 653-658. [CrossRef]

32. Johns, I.C.; Adams, E.-L. Trends in antimicrobial resistance in equine bacterial isolates: 1999-2012. Vet. Rec. 2015, 176, 334. [CrossRef]

33. Colodner, R.; Rock, W.; Chazan, B.; Keller, N.; Guy, N.; Sakran, W.; Raz, R. Risk factors for the development of extended-spectrum beta-lactamase-producing bacteria in nonhospitalized patients. Eur. J. Clin. Microbiol. Infect. Dis. Off. Publ. Eur. Soc. Clin. Microbiol. 2004, 23, 163-167. [CrossRef]

34. Vázquez-Martínez, E.R.; García-Gómez, E.; Camacho-Arroyo, I.; González-Pedrajo, B. Sexual dimorphism in bacterial infections. Biol. Sex. Differ. 2018, 9, 27. [CrossRef]

35. Adler, A.; Sturlesi, N.; Fallach, N.; Zilberman-Barzilai, D.; Hussein, O.; Blum, S.E.; Klement, E.; Schwaber, M.J.; Carmeli, Y. Prevalence, Risk Factors, and Transmission Dynamics of Extended-Spectrum- $\beta$-Lactamase-Producing Enterobacteriaceae: A National Survey of Cattle Farms in Israel in 2013. J. Clin. Microbiol. 2015, 53, 3515-3521. [CrossRef]

36. McGowan, C. Welfare of Aged Horses. Animals 2011, 1, 366-376. [CrossRef] [PubMed]

37. Monroe, M.; Whitworth, J.D.; Wharton, T.; Turner, J. Effects of an Equine-Assisted Therapy Program for Military Veterans with Self-Reported PTSD. Soc. Amp Anim. 2019, 1, 1-14. [CrossRef]

38. Borgi, M.; Loliva, D.; Cerino, S.; Chiarotti, F.; Venerosi, A.; Bramini, M.; Nonnis, E.; Marcelli, M.; Vinti, C.; De Santis, C.; et al. Effectiveness of a Standardized Equine-Assisted Therapy Program for Children with Autism Spectrum Disorder. J. Autism Dev. Disord. 2016, 46, 1-9. [CrossRef] [PubMed] 
39. White-Lewis, S.; Johnson, R.; Ye, S.; Russell, C. An equine-assisted therapy intervention to improve pain, range of motion, and quality of life in adults and older adults with arthritis: A randomized controlled trial. Appl. Nurs. Res. 2019, 49, 5-12. [CrossRef]

40. Linder, D.E.; Mueller, M.K.; Gibbs, D.M.; Siebens, H.C.; Freeman, L.M. The Role of Veterinary Education in Safety Policies for Animal-Assisted Therapy and Activities in Hospitals and Nursing Homes. J. Vet. Med. Educ. 2016, 44, 229-233. [CrossRef]

41. Royden, A.; Ormandy, E.; Pinchbeck, G.; Pascoe, B.; Hitchings, M.D.; Sheppard, S.K.; Williams, N.J. Prevalence of faecal carriage of extended-spectrum $\beta$-lactamase (ESBL)-producing Escherichia coli in veterinary hospital staff and students. Vet. Rec. Open 2019, 6, e000307. [CrossRef]

(C) 2020 by the authors. Licensee MDPI, Basel, Switzerland. This article is an open access article distributed under the terms and conditions of the Creative Commons Attribution (CC BY) license (http://creativecommons.org/licenses/by/4.0/). 